\title{
Maternal adipose tissue, antenatal steroids, and Respiratory Distress syndrome: complex relations
}

\author{
Hasan Tolga Çelik ${ }^{1}$, Ayşe Korkmaz¹, Özgür Özyünc $\ddot{u}^{2}$, Şule Yiğit ${ }^{1}$, Murat Yurdakök ${ }^{1}$ \\ ${ }^{1}$ Division of Neonatology, Department of Pediatrics, ${ }^{2}$ Department of Obstetrics and Gynecology, Hacettepe University \\ Faculty of Medicine, Ankara, Turkey. E-mail: htcelik@gmail.com \\ Received: 18th March 2019, Revised: 6th May 2019, Accepted: 7th May 2019
}

SUMMARY: Çelik HT, Korkmaz A, Özyüncü Ö, Yiğit Ş, Yurdakök M. Maternal adipose tissue, antenatal steroids, and Respiratory Distress syndrome: complex relations. Turk J Pediatr 2019; 61: 859-866.

The incidences of maternal obesity and obesity-related maternal, fetal and neonatal complications have increased considerably. Obese people may have lower, normal or increased fat mass independent from their body mass index. We aimed to investigate the relationships between antenatal steroid therapy and maternal body fat ratio for the risk of Respiratory distress syndrome (RDS) in preterm infants.

Pregnant women and their newborn infants between 24-34 weeks of gestation, who received a full course of antenatal steroid therapy were included in the study. Mother's body weight, body mass index (BMI), and body compositions (muscle, fat, water) were calculated using the bioelectrical impedance method 5 days after giving birth. Neonatal characteristics and respiratory outcomes were noted.

A total of 42 mothers and their single premature infants were included in the study. Nineteen (45.2\%) infants developed RDS (Group 1) while $23(54.8 \%)$ infants did not develop RDS (Group 2). The mean body fat mass (kg), fat ratio (\%), truncal fat mass $(\mathrm{kg})$, and truncal fat ratio (\%) were statistically significantly higher in Group 1 than in Group 2. The incidence of RDS was significantly higher in the group of mothers with a body fat ratio $>30.0 \%$ $(\mathrm{n}=15 / 24,62.5 \%)$ when compared with the group of mothers with a body fat ratio $\leq 30 \%(n=4 / 18,22.2 \%)(p=0.013)$.

Maternal adipose tissue plays an important role and should be taken into consideration especially in obese women, before giving antenatal steroids to achieve positive effects of the therapy in preterm infants.

Key words: premature, newborn, maternal adipose tissue, antenatal steroid, respiratory distress syndrome, RDS.

Antenatal steroid therapy, which is applied to pregnant women who are at high risk of preterm delivery between 24-34 weeks of gestation, has been shown to decrease the frequency and severity of neonatal respiratory distress syndrome (RDS) and the risk of neonatal mortality by accelerating fetal lung maturity. ${ }^{1}$ Currently, antenatal steroid therapy is one of the most evidence-based perinatal approaches and is recommended by many obstetric organizations and societies. ${ }^{2}$ Betamethasone (two doses of $12 \mathrm{mg}$ given intramuscularly (IM) 24 hours apart) is the most commonly used corticosteroid drug for fetal lung maturation. ${ }^{3}$ However, the effectiveness of antenatal steroid therapy may 
be altered by many maternal, placental, and fetal factors and cannot always prevent the development of RDS in the preterm infant.

In the last decades, the prevalence of obesity has increased dramatically all over the world..$^{4,5}$ In accordance with this, the incidences of maternal obesity and obesity-related maternal, fetal, and neonatal complications have increased considerably. These complications include gestational diabetes, hypertensive pregnancy disorders, intrauterine fetal death, preterm birth, and related neonatal morbidities. ${ }^{6,9}$ Maternal metabolic abnormalities, inflammation, and alterations in placental transport can contribute directly or indirectly to altered regulation of fetal lung development and may cause respiratory morbidities in the newborn infant. ${ }^{10,11}$ Obesity also changes body composition and physiology, and this may alter the pharmacokinetic parameters of drugs such as absorption, volume of distribution, and clearance. ${ }^{12}$

Furthermore, the dose of antenatal bethametasone is constant regardless of the mother's body weight. ${ }^{2,3}$ In addition, as the length of the syringe needle is standard, and fat tissue thickness is increased in obese patients, an intramuscular injection of betamethasone may not reach muscular tissue, and it may infiltrate the fat tissue. Steroid drugs are known to have an affinity to the adipose tissue, and this "intra-adipose" injection may cause different drug effects and pharmacokinetics. In two recent studies, maternal body mass index (BMI) has not been found to effect neonatal prematurityrelated morbidities in those receiving antenatal steroids. ${ }^{13,14}$ In these studies, only prepregnancy BMI was used to identify obese and nonobese mothers. Antenatal steroids are commonly applied during the second trimester of pregnancy when most of the gestational weight gain has already occurred, and BMI has changed. Additionally, although frequently used to classify obesity, BMI does not measure adiposity, as it is calculated using only height and weight, not body composition. Obese people may have lower, normal, or increased fat mass independent from their BMI. Therefore, in this study, we aimed to investigate the relationships between antenatal steroid therapy and maternal body fat ratio for the risk of RDS in preterm infants.

\section{Material and Methods}

This study was conducted at the Neonatal Intensive Care Unit of Hacettepe University Hospital. Pregnant women and their newborn infants between 24-34 weeks of gestation and who received a full course of antenatal steroid therapy (single course, $2 \times 12 \mathrm{mg}$ betamethasone, 24 hours apart, IM) at least 48 hours before delivery and a maximum of 7 days after therapy were included in the study. ${ }^{2}$ Women with multiple pregnancies, type 1,2 , and gestational diabetes, chronic hypertensive disorders or preeclampsia with disturbed fetal hemodynamics, maternal use of systemic corticosteroids for other acute or chronic disorders, premature rupture of membranes $>3$ days with/without maternal chorioamnionitis, small- or large-for-gestational-age infants, infants with congenital pneumonia or early neonatal sepsis, metabolic diseases, immune or nonimmune hydrops fetalis, and congenital anomalies were excluded from the study.

Body weight, BMI, and body compositions (muscle, fat, water) were calculated using the bioelectrical impedance method 5 days after birth (TANITA Segmental Body Composition Analyser BC-418, Illinois, USA). This measurement was done in the fasting condition with minimal clothes and without shoes, after defecation and urination, at 8:009:00 am in the morning. Height was measured to the nearest $0.5 \mathrm{~cm}$ without shoes using a digital meter mounted on a wall. BMI was calculated using the formula: weight $(\mathrm{kg})$ divided by height in meters squared, which was automatically performed by the TANITA analyzer. Standard cut-points were used. Underweight was defined as a BMI $<18.5$, normal weight included BMI values between 18.5 and $<25.0$, overweight included BMI values from $\geq 25.0$ to $<30.0$, obesity was defined as a BMI $>30.0 \mathrm{~kg} / \mathrm{m}^{2}$, and a high maternal body fat ratio was defined as $\geq 30 \%$, while a normal body fat ratio in women was defined as $25-30 \%$. ${ }^{15,16}$

In our study, body composition analysis using the bioelectrical impedance method was not done just before delivery, as it is contraindicated 
for the fetus, and at least 5 days were allowed for the mother to lose edema after delivery. Maternal prepregnancy body weights were not taken into consideration, as antenatal steroids are given during pregnancy between 24-34 weeks of gestation, and the mothers have already gained weight due to gestation. In addition, most of the mothers change their nutrition habits, eat more, and gain a weight during pregnancy. Therefore, we used the early postpartum maternal body weights to represent "pregnancy body weights."

In preterm infants, demographic and clinical characteristics including gender, gestational age, birth weight, mode of delivery, Apgar scores, and the development of RDS and major neonatal morbities were noted. RDS was defined by the presence of respiratory distress (grunting, tachypnea, retractions, cyanosis); supplemental oxygen and/or positive pressure ventilation requirement; typical chest X-ray findings with reticulogranular patterns, air bronchograms or a ground glass appearance in the absence of all signs of suspected/proven infection (pneumonia) such as: a) history of maternal chorioamnionitis or maternal urinary tract infection, b) an elevated or decreased leukocyte count $\left(>25000 / \mathrm{mm}^{3}\right.$ or $<5000 /$ $\left.\left.\mathrm{mm}^{3}\right), \mathrm{c}\right)$ an elevated serum CRP ( $>2 \mathrm{mg} /$ $\mathrm{dL})$ or procalcitonin level $(>2 \mathrm{mg} / \mathrm{dL})$, and a positive blood or tracheal aspirate culture, which was obtained on the first day of life. ${ }^{17}$

The study was approved by Hacettepe University Ethics Committee Local Ethics Committee for Medical Research (GO15/48016), and written informed consents were obtained from each mother prior to enrollment in the study.

\section{Statistical Analysis}

Statistical analyses were performed with the Statistical Package for the Social Sciences 18.0 (SPSS, Inc., Chicago, IL, USA). Normally distributed variables were analyzed with parametric tests (independent samples t-test). Nonnormally distributed variables were analyzed with nonparametric tests (MannWhitney U test). Fisher's exact test and chisquare tests were used for categorical and qualitative variables. A $p$ value of $<0.05$ was considered statistically significant.

\section{Results}

A total of 42 mothers and their single premature infants were included in the study. Nineteen (45.2\%) infants developed RDS (Group 1), while 23 (54.8\%) infants did not develop RDS (Group 2). There were no statistically significant differences in the mean gestational age and birth weight between the two groups $(30.5 \pm 2.5$ wk vs. $31.8 \pm 2.2 \mathrm{wk}, \mathrm{p}=0.075$ and $1335 \pm 471 \mathrm{~g}$ vs. $1537 \pm 468 \mathrm{~g}, \mathrm{p}=0.172)$. The two groups were also similar in the incidences of various neonatal morbidities (Table I).

There were no statistically significant differences between the incidences of maternal overweight (BMI: 25-29.9) and maternal obesity (BMI $\geq 30$ ) between the groups $(73.7 \%$ vs. $65.2 \%, \mathrm{p}=0.555$ and $36.8 \%$ vs. $17.4 \%$, $\mathrm{p}=0.180$ in Group 1 and 2, respectively). Among maternal anthropometric parameters, which were determined by bioelectrical impedance, the mean BMI were statistically similar in both groups (28.3 \pm 6.4 in Group 1 and 26.7 \pm 4.9 in Group 2, p=0.369). However, the mean body fat mass $(\mathrm{kg})$, fat ratio (\%), truncal fat mass $(\mathrm{kg})$, and truncal fat ratio (\%) were statistically significantly higher in Group 1 than in Group 2 (Table II).

The incidence of RDS was $38.5 \%(n=5)$ in the group of mothers with a BMI $<25(\mathrm{n}=13)$, and $48.3 \%(\mathrm{n}=14)$ in the group of mothers with a BMI $\geq 25(n=29)(p=0.555)$. However, the incidence of RDS was significantly higher in the group of mothers with a body fat ratio $>30.0 \%(\mathrm{n}=15 / 24,62.5 \%)$ when compared with the group of mothers with a body fat ratio $\leq 30 \%(\mathrm{n}=4 / 18,22.2 \%)(\mathrm{p}=0.013)$.

The distribution of the body mass indexes and body fat ratios in all mothers $(n=42)$ are given in Table III.

\section{Discussion}

This is the first study in the literature investigating the relationship between maternal body composition, adipose tissue, and antenatal steroid therapy from the point of developing RDS in preterm infants. Antenatal steroid therapy for the prevention of RDS in preterm infants has been one of the most evidence-based approaches in perinatology for 
Table I. Demographic and Clinical Characteristics of the Preterm Infants in Both Groups.

\begin{tabular}{|c|c|c|c|}
\hline & $\begin{array}{c}\text { Group } 1 \\
\text { RDS (+) } \\
n=19\end{array}$ & $\begin{array}{c}\text { Group } 2 \\
\text { RDS (-) } \\
n=23\end{array}$ & $\mathrm{P}$ \\
\hline Gender $(\mathrm{M} / \mathrm{F}), \mathrm{n}(\%)$ & $10(52.6) / 9(47.4)$ & $13(56.5) / 10(43.5)$ & 0.658 \\
\hline \multirow[t]{2}{*}{ Gestational age (wk), mean \pm SD (range) } & $30.5 \pm 2.5$ & $31.8 \pm 2.2$ & 0.079 \\
\hline & $(26-34)$ & $(25-34)$ & \\
\hline \multirow[t]{2}{*}{ Birth weight $(\mathrm{g})$, mean \pm SD (range) } & $1335 \pm 471$ & $1537 \pm 468$ & 0.173 \\
\hline & $(870-2430)$ & $(480-2300)$ & \\
\hline Perinatal hypoxia, n (\%) & $1(5.3)$ & - & 0.452 \\
\hline Mode of delivery (V/CS), n (\%) & $2(10.5) / 17(89.5)$ & $2(8.7) / 21(91.3)$ & \\
\hline \multirow[t]{2}{*}{ Apgar score (5th min.), mean \pm SD (range) } & $7.2 \pm 1.5$ & $8.2 \pm 1.6$ & 0.048 \\
\hline & $(5-10)$ & $(5-10)$ & \\
\hline Resuscitation at birth, n (\%) & $8(42.1)$ & $8(34.8)$ & \\
\hline \multirow[t]{2}{*}{ Cord blood arterial $\mathrm{pH}$, mean $\pm \mathrm{SD}$ (range) } & $7.33 \pm 0.1$ & $7.29 \pm 0.1$ & 0.407 \\
\hline & $(6.99-7.48)$ & $(7.12-7.43)$ & \\
\hline \multirow{2}{*}{$\begin{array}{l}\text { Duration of mechanical ventilation (day), median } \\
\text { (range) }\end{array}$} & 5 & 0 & 0.055 \\
\hline & $(0-31)$ & $(0-23)$ & \\
\hline \multirow[t]{2}{*}{ Duration of oxygen support (day), median (range) } & 2 & 0 & 0.120 \\
\hline & $(0-31)$ & $(0-35)$ & \\
\hline \multirow{2}{*}{$\begin{array}{l}\text { Duration of hospitalization (day), mean } \pm \text { SD } \\
\text { (range) }\end{array}$} & $28.5 \pm 16.7$ & $15.9 \pm 12.3$ & 0.156 \\
\hline & $(2-58)$ & $(3-59)$ & \\
\hline Apnea of prematurity, n (\%) & $5(26.3)$ & $3(13.0)$ & 0.433 \\
\hline Postnatal pneumonia, n (\%) & $4(21.1)$ & $4(17.4)$ & 0.764 \\
\hline Patent ductus arteriosus, $\mathrm{n}(\%)$ & $7(36.8)$ & $3(13.0)$ & 0.143 \\
\hline Necrotizing enterocolitis (stage $2-3$ ), n (\%) & $1(5.3)$ & $1(4.3)$ & 1.000 \\
\hline Neonatal sepsis, n (\%) & $2(10.5)$ & $3(13.0)$ & 0.458 \\
\hline Intraventricular hemorrhage (all grades), n (\%) & $1(5.3)$ & - & 0.452 \\
\hline Bronchopulmonary dysplasia, n (\%) & $3(15.8)$ & $1(4.3)$ & 0.313 \\
\hline Mortality, n (\%) & $1(5.3)$ & $2(8.7)$ & 0.645 \\
\hline
\end{tabular}

decades. However, our study has shown that maternal adipose tissue plays an important role and should be taken into consideration especially in obese women before giving antenatal steroids to achieve the positive effects of the therapy in preterm infants.

We thought there might be a few possible causes leading to these results. In the literature, it has been shown by ultrasonographic examinations that standard needles are not long enough to reach the gluteal muscle mass in IM injections. ${ }^{18}$ The simplest hypothesis is that an insufficient dose of betamethasone reaches the muscular tissue and systemic circulation, as the length of the standard needle might be short for IM injection because of the increased thickness of the gluteal fat mass in obese pregnant women. Therefore, betamethasone will actually be injected into the fat tissue, and the absorption, distribution, and metabolism (pharmacokinetics) of the drug could be altered. This may cause a lower maternal plasma level and placental transfer of the drug and decreased effectivity in the fetal lung tissue. 
Table II. Maternal Bioelectrical Impedance Measurements of Body Composition in Both Groups.

\begin{tabular}{|c|c|c|c|}
\hline & $\begin{array}{c}\text { Group } 1 \\
\text { RDS (+) } \\
\mathrm{n}=19\end{array}$ & $\begin{array}{c}\text { Group } 2 \\
\text { RDS (-) } \\
\mathrm{n}=23\end{array}$ & $\mathrm{P}$ \\
\hline Maternal age (year), mean \pm SD (range) & $\begin{array}{c}30.3 \pm 5.4 \\
(20-39)\end{array}$ & $\begin{array}{c}29.2 \pm 6.8 \\
(19-44)\end{array}$ & 0.547 \\
\hline Maternal body weight $(\mathrm{kg})$, mean \pm SD (range) & $\begin{array}{l}73.9 \pm 14.5 \\
(46.8-101.1)\end{array}$ & $\begin{array}{l}66.1 \pm 12.6 \\
(49.7-96.3)\end{array}$ & 0.071 \\
\hline Maternal height $(\mathrm{cm})$, mean \pm SD (range) & $\begin{array}{l}162 \pm 5.8 \\
(152-172)\end{array}$ & $\begin{array}{l}160 \pm 6.9 \\
(150-174)\end{array}$ & 0.313 \\
\hline Body mass index (BMI), mean \pm SD (range) & $\begin{array}{l}28.3 \pm 6.4 \\
(17.8-43.8)\end{array}$ & $\begin{array}{l}26.7 \pm 4.9 \\
(18.5-38.1)\end{array}$ & 0.369 \\
\hline Maternal overweight (BMI: 25-29.9), n (\%) & $7(36.8)$ & $11(47.8)$ & 0.474 \\
\hline Maternal obesity $(\mathrm{BMI} \geq 30), \mathrm{n}(\%)$ & $7(36.8)$ & $4(17.4)$ & 0.180 \\
\hline Maternal overweight + obesity, $(\mathrm{BMI} \geq 25), \mathrm{n}(\%)$ & $14(73.7)$ & $15(65.2)$ & 0.555 \\
\hline Maternal body fat ratio $>30 \%, \mathrm{n}(\%)$ & $15(78.9)$ & $9(39.1)$ & 0.013 \\
\hline Body fat mass $(\mathrm{kg})$, mean \pm SD (range) & $\begin{array}{c}25.7 \pm 10.1 \\
(7.7-49.5)\end{array}$ & $\begin{array}{l}19.3 \pm 6.3 \\
(8.5-34.3)\end{array}$ & 0.023 \\
\hline Body fat ratio (\%), mean \pm SD (range) & $\begin{array}{l}33.5 \pm 8.2 \\
(14.3-48.9)\end{array}$ & $\begin{array}{l}27.9 \pm 6.1 \\
(15.9-36.5)\end{array}$ & 0.016 \\
\hline Truncal fat mass $(\mathrm{kg})$, mean $\pm \mathrm{SD}$ (range) & $\begin{array}{l}12.2 \pm 5.2 \\
(2.5-22.5)\end{array}$ & $\begin{array}{l}8.2 \pm 3.0 \\
(2.7-13.1)\end{array}$ & 0.006 \\
\hline Truncal fat ratio $(\%)$, mean \pm SD (range) & $\begin{array}{c}30.2 \pm 9.3 \\
(9.1-44.3)\end{array}$ & $\begin{array}{c}22.8 \pm 6.8 \\
(8.8-33.9)\end{array}$ & 0.007 \\
\hline Body fat free mass $(\mathrm{kg})$, mean \pm SD (range) & $\begin{array}{l}48.3 \pm 6.3 \\
(37.0-62.8)\end{array}$ & $\begin{array}{c}48.5 \pm 5.3 \\
(39-62.1)\end{array}$ & 0.892 \\
\hline Truncal fat free mass $(\mathrm{kg})$, mean $\pm \mathrm{SD}$ (range) & $\begin{array}{l}26.7 \pm 2.8 \\
(21.0-31.7)\end{array}$ & $\begin{array}{l}27.2 \pm 2.4 \\
(21.7-33.5)\end{array}$ & 0.563 \\
\hline Truncal muscle mass $(\mathrm{kg})$, mean $\pm \mathrm{SD}$ (range) & $\begin{array}{l}25.5 \pm 2.7 \\
(20.1-30.3)\end{array}$ & $\begin{array}{l}25.9 \pm 2.3 \\
(20.8-32.0)\end{array}$ & 0.569 \\
\hline Total body water $(\mathrm{kg})$, mean \pm SD (range) & $\begin{array}{l}35.3 \pm 4.6 \\
(27.1-46.0)\end{array}$ & $\begin{array}{l}35.5 \pm 3.9 \\
(28.6-45.5)\end{array}$ & 0.892 \\
\hline
\end{tabular}

BMI: body mass index, SD: standart deviation

Table III. The Distribution of the Body Mass Indexes and Body Fat Ratios in All Mothers $(n=42)$.

\begin{tabular}{lcc}
\hline & $\begin{array}{c}\text { BMI }<25 \\
\mathrm{n}(\%)\end{array}$ & $\begin{array}{c}\text { BMI } \geq 25 \\
\mathrm{n}(\%)\end{array}$ \\
\hline Body fat ratio $<30 \%$ & $11(26.2 \%)$ & $7(16.7 \%)$ \\
Body fat ratio $\geq 30 \%$ & $2(4.8 \%)$ & $22(52.4 \%)$
\end{tabular}

BMI: body mass index 
In the literature, there are many studies comparing the pharmacokinetics of steroid drugs between normal weight and obese individuals. In a study investigating the bioavailability of IM human chorionic gonadotropin (hCG) used for in-vitro fertilization treatment, after both IM and SC application, serum hCG levels have been found to be significantly lower in obese patients compared to nonobese. ${ }^{19}$ However in another study on infertility treatment, there were no significant differences between serum hCG concentrations measured after 12 hours of IM and SC applications. The authors have found a strong negative correlation between BMI and serum hCG levels and commented that the circulating hCG levels were determined mostly by body mass rather than the route of application. ${ }^{20}$ In another study, maternal and umbilical cord blood serum betamethasone concentrations were found to be similar in obese and nonobese women. ${ }^{21}$ In our study, we did not measure maternal or neonatal serum betamethasone concentrations because of this information in the literature. In addition, a drug's serum level may not correlate with its tissue level or effects.

The second hypothesis may be possible: an altered metabolism of the betamethasone in the adipose tissue. Obesity changes body composition and physiology, leading to increases in lean body mass, fat mass, and the proportion of extracellular water to total body water. In obesity, blood volume, cardiac output, and renal blood flow are also increased. These changes can alter pharmacokinetic parameters such as drug absorption, volume of distribution, and clearance. ${ }^{12}$ Steroid drugs are highly lipophilic and, in their target tissues, steroids are concentrated by an uptake mechanism that relies on their binding to intracellular receptors. Their distribution volume is increased and potentially necessitates increased dosing. Although this has not been shown to be consistent with certain highly lipophilic drugs, a linear relationship has been found between the pharmacokinetic properties of betamethasone and maternal lean body weight, and individualization of the betamethasone dose due to maternal lean body mass has been suggested. ${ }^{22,23}$
Adipose tissue expresses numerous receptors that allow it to respond to afferent signals from other endocrine organs, in particular, many enzymes for the activation, interconversion, and inactivation of steroid hormones. Several steroidogenic enzymes are expressed in adipose tissue, and this tissuespecific glucocorticoid metabolism is primarily determined by the enzyme 11- $\beta$-hydroxysteroid dehydrogenase (HSD)-1, which catalyzes the hormonally inactive 11- $\beta$-ketoglucocorticoid metabolites (cortisone) to hormonally active 11- $\beta$-hydroxylated metabolite (cortisol). $11-\beta$-HSD1 is highly expressed in adipose tissue, particularly in visceral adipose tissue. Although 11-в-HSD1 amplifies local glucocorticoid concentrations within adipose tissue, it does not contribute significantly to systemic glucocorticoid concentrations. ${ }^{24,26}$ Therefore, betamethosone trapped in the adipose tissue of an obese pregnant women might have transformed to another ineffective metabolite.

Apart from an altered maternal and fetal effective betamethasone dose and pharmacokinetics, obesity or increased fat mass itself can have negative effects on the developing fetal lung, leading to RDS in the postnatal period. Adipose tissue is the largest endocrine organ in the body, and increased adiposity has been found to be related with increased oxidative stress, inflammation, insulin resistance, dysregulation of the maternal hypothalamic-pituitary-adrenal axis, altered glucocorticoid-mediated fetal lung development, and surfactant maturation leading to fetal lung injury and concomitantly disturbed fetal programming. ${ }^{11}$

The main limitation of our study was the relatively small number of cases and control groups, as we have excluded all cases with maternal obstetric and neonatal morbidities affecting the development of RDS in preterm infants to homogenize our study group. Most studies related to antenatal steroids have been performed in an era when obesity was not an epidemic problem worldwide. However, our study has shown that maternal adipose tissue plays an important role and should be taken into consideration in obese women before giving antenatal steroids. The exact physiological/pharmacokinetic mechanisms 
of antenatal steroid therapy should be investigated in different patient populations. In the future, this may lead to modifications in the type, dose, or method of antenatal steroids administration for an optimal response in fetal lung.

\section{REFERENCES}

1. Roberts D, Brown J, Medley N, Dalziel SR. Antenatal corticosteroids for accelerating fetal lung maturation for women at risk of preterm birth. Cochrane Database Syst Rev 2017; 3: CD004454.

2. Committee on Obstetric Practice. Committee Opinion No. 713: Antenatal Corticosteroid Therapy for Fetal Maturation. Obstet Gynecol 2017; 130: e102-e109.

3. Brownfoot FC, Gagliardi DI, Bain E, Middleton P, Crowther CA. Different corticosteroids and regimens for accelerating fetal lung maturation for women at risk of preterm birth. Cochrane Database Syst Rev 2013; 8: CD006764.

4. Flegal KM, Carroll MD, Ogden CL, Johnson CL. Prevalence and trends in obesity among US adults, 1999-2000. JAMA 2002; 288: 1723-1727.

5. Walls HL, Magliano DJ, Stevenson CE, et al. Projected progression of the prevalence of obesity in Australia. Obesity (Silver Spring) 2012; 20: 872-878.

6. Poston L, Caleyachetty $\mathrm{R}$, Cnattingius S, et al. Preconceptional and maternal obesity: epidemiology and health consequences. Lancet Diabetes Endocrinol 2016; 4: 1025-1036.

7. Kim T, Burn SC, Bangdiwala A, Pace S, Rauk P. Neonatal morbidity and maternal complication rates in women with a delivery body mass index of 60 or higher. Obstet Gynecol 2017; 130: 988-993.

8. Smid MC, Vladutiu CJ, Dotters-Katz SK, Manuck TA, Boggess KA, Stamilio DM. Maternal super obesity and neonatal morbidity after term cesarean delivery. Am J Perinatol 2016; 33: 1198-1204.

9. Zhong Y, Cahill AG, Macones GA, Zhu F, Odibo AO. The association between prepregnancy maternal body mass index and preterm delivery. Am J Perinatol 2010; 27: 293-298.

10. Ramsay JE, Ferrell WR, Crawford L, Wallace AM, Greer IA, Sattar N. Maternal obesity is associated with dysregulation of metabolic, vascular, and inflammatory pathways. J Clin Endocrinol Metab 2002; 87: 4231-4237.

11. McGillick EV, Lock MC, Orgeig S, Morrison JL. Maternal obesity mediated predisposition to respiratory complications at birth and in later life: understanding the implications of the obesogenic intrauterine environment. Paediatr Respir Rev 2017; 21: 11-18
12. Rowe S, Siegel D, Benjamin DK Jr; Best Pharmaceuticals for Children Act -Pediatric Trials Network Administrative Core Committee. Gaps in Drug Dosing for Obese Children: A Systematic Review of Commonly Prescribed Emergency Care Medications. Clin Ther 2015; 37: 1924-1932.

13. Claire L, Vieux R. Efficacy of antenatal corticosteroids according to maternal and perinatal factors: a retrospective cohort study. Am J Perinatol 2015; 32: 1070-1077.

14. Hashima JN, Lai Y, Wapner RJ, et al; Eunice Kennedy Shriver National Institute of Child Health and Human Development Maternal-Fetal Medicine Units Network. The effect of maternal body mass index on neonatal outcome in women receiving a single course of antenatal corticosteroids. Am J Obstet Gynecol 2010; 202: 263.e1-263.e5.

15. Thompson PD, Arena R, Riebe D, Pescatello LS; American College of Sports Medicine. ACSM's new preparticipation health screening recommendations from ACSM's guidelines for exercise testing and prescription, ninth edition. Curr Sports Med Rep 2013; 12: 215-217.

16. Gallagher D, Heymsfield SB, Heo M, Jebb SA, Murgatroyd PR, Sakamoto Y. Healthy percentage body fat ranges: an approach for developing guidelines based on body mass index. Am J Clin Nutr 2000; 72: 694-701.

17. Hamvas A. Pathophysiology and management of respiratory distress syndrome. In: Martin RJ, Fanaroff AA, Walsh MC (eds). Fanaroff and Martin's NeonatalPerinatal Medicine (9th ed) Vol 1. St. Louis: Elsevier Mosby, 2011: 1106-1116.

18. Nisbet AC. Intramuscular gluteal injections in the increasingly obese population: retrospective study. BMJ 2006; 332: 637-638.

19. Chan CC, Ng EH, Chan MM, et al. Bioavailability of hCG after intramuscular or subcutaneous injection in obese and non-obese women. Hum Reprod 2003; 18 : 2294-2297.

20. Elkind-Hirsch KE, Bello S, Esparcia L, Phillips K, Sheiko A, McNichol M. Serum human chorionic gonadotropin levels are correlated with body mass index rather than route of administration in women undergoing in vitro fertilization-embryo transfer using human menopausal gonadotropin and intracytoplasmic sperm injection. Fertil Steril 2001; 75: 700-704.

21. Gyamfi C, Mele L, Wapner RJ, et al; Eunice Kennedy Shriver National Institute of Child Health and Human Development Maternal-Fetal Medicine Units Network. The effect of plurality and obesity on betamethasone concentrations in women at risk for preterm delivery. Am J Obstet Gynecol 2010; 203: 219.e1-5.

22. Barras M, Legg A. Drug dosing in obese adults. Aust Prescr 2017; 40: 189-193. 
23. Della Torre $\mathrm{M}$, Hibbard JU, Jeong $\mathrm{H}$, Fischer $\mathrm{JH}$. Betamethasone in pregnancy: influence of maternal body weight and multiple gestation on pharmacokinetics. Am J Obstet Gynecol 2010; 203: 254.e1-12.

24. Li J, Daly E, Campioli E, Wabitsch M, Papadopoulos V. De novo synthesis of steroids and oxysterols in adipocytes. J Biol Chem 2014; 289: 747-764.
25. Chapman K, Holmes M, Seckl J. 11ß-hydroxysteroid dehydrogenases: intracellular gate-keepers of tissue glucocorticoid action. Physiol Rev 2013; 93: 11391206.

26. Morton NM. Obesity and corticosteroids: 11betahydroxysteroid type 1 as a cause and therapeutic target in metabolic disease. Mol Cell Endocrinol 2010; 316: 154-164. 